כ OPEN ACCESS

\title{
PENGARUH KEPERCAYAAN DIRI DAN KEMAMPUAN KOMUNIKASI TERHADAP KEMAMPUAN PUBLIC SPEAKING MAHASISWA PGSD
}

\author{
Dyah Indraswati*, Husniati, Ida Ermiana, Arif Widodo, Mohammad Archi \\ Maulyda \\ PGSD, FKIP, Universitas Mataram \\ Email: dyahindraswati@unram.ac.id* \\ KEYWORDS: self-confidence; communication skills; public speaking skills
}

\begin{abstract}
This study aims to determine: (1) The effect of self-confidence on the ability of public speaking; (2) The effect of communication skills on public speaking skills; (3) The effect of self confidence and communication ability on public speaking ability of Elementary School Teacher Education Students 2019, Faculty of Teacher Training and Education, University of Mataram. This research is an ex post facto study using a quantitative data approach. The subjects in this study were students of class 2019 , amounting to 345 and then taken as many as $38 \%$ of the population of around 131 students. Analysis Methods of data collection using a questionnaire. Test the validity of the instrument using Product Moment correlation and reliability testing using Alpha Cronbach. Data analysis uses descriptive statistical analysis; analysis prerequisite test consisting of normality test, linearity test, and multicollinearity test; and regression analysis consisting of a simple linear regression test and multiple linear regression test. The results showed: (1) There was a positive and significant effect of self- confidence on the public speaking ability. (2) There is a positive and significant influence of communication ability on the public speaking ability. (3) There is a positive and significant influence of self-confidence and communication ability on the public speaking ability.
\end{abstract}

\section{ABSTRAK}

Penelitian ini bertujuan untuk mengetahui: (1) Pengaruh kepercayaan diri terhadap kemampuan public speaking; (2) Pengaruh kemampuan berkomunikasi terhadap kemampuan public speaking; (3) Pengaruh kepercayaan diri dan kemampuan berkomunikasi terhadap kemampuan public speaking Mahasiswa Pendidikan Guru Sekolah Dasar Angkatan 2019, Fakultas Keguruan dan IImu Pendidikan, Universitas Mataram. Penelitian ini merupakan penelitian expost facto dengan menggunakan pendekatan data kuantitatif. Subyek dalam penelitian ini adalah mahasiswa angkatan 2019 yang berjumlah 345 kemudian diambil sampel sebanyak 38\% dari jumlah populasi atau sekitar 131 mahasiswa. Analisis Metode pengumpulan data menggunakan angket. Uji validitas instrumen menggunakan korelasi Product Moment dan uji reliabilitas menggunakan Alpha Cronbach. Analisis data menggunakan analisis statistik deskriptif; uji prasyarat analisis yang terdiri dari uji normalitas, uji linearitas, dan uji multikolinearitas; dan analisis regresi yang terdiri dari uji regresi linear sederhana dan uji regresi linear ganda. Hasil penelitian menunjukkan: (1) Terdapat pengaruh positif dan signifikan kepercayaan diri terhadap kemampuan public speaking mahasiswa prodi PGSD, FKIP, Universitas Mataram. (2) Terdapat pengaruh positif dan signifikan kemampuan berkomunikasi terhadap kemampuan public speaking mahasiswa prodi PGSD, FKIP, Universitas Mataram. (3) Terdapat pengaruh positif dan signifikan kepercayaan diri dan kemampuan komunikasi terhadap kemampuan public speaking mahasiswa prodi PGSD, FKIP, Universitas Mataram. 
Pendidikan mempunyai tanggung jawab besar dalam mempersiapkan peserta didik menghadapi tantangan masa depan (Widodo, Indraswati, \& Sobri, 2019). Kondisi peserta didik di Indonesia beraneka ragam, maka dari itu pemerintah harus memberikan kesempatan bagi setiap peserta didik meraih pendidikan yang berkualitas (Deni Sutisna, Dyah Indraswati, Nursaptini, Setiani Novitasari, 2020). Menghadapi tantangan abad 21 memerlukan terobosan dan pemikiran yang baru agar output yang dihasilkan bermutu dan berkualitas (Indraswati, Marhayani, Sutisna, \& Widodo, 2020) . Kualitas guru menentukan kualitas pendidikan di Indonesia (Sutisna, Indraswati, \& Sobri, 2019). Guru perlu meningkatkan kompetensi dalam memberikan layanan belajar (Arif Widodo, Dyah Indraswati, 2020). Kualitas guru dapat dilihat dari empat kompetensi diantaranya kompetensi pedagogik, kompetensi kepribadian, kompetensi profesional, dan kompetensi sosial. Keempat kompetensi ini memerlukan kemampuan komunikasi yang baik. Kualitas seorang guru dapat dilihat dari kemampuan menyampaikan materi pelajaran dan mengelola kelas. Motivasi belajar peserta didik dapat meningkat apabila guru dapat menyampaikan materi dengan semangat dan komunikatif (Widodo, Indraswati, Novitasari, Rahmatih, \& Mataram, 2020). Guru harus mampu merancang model pembelajaran yang mampu membuat peserta didik mengonstruk konsep melalui berbagai tahapan seperti mengamati, menanya, mengumpulkan informasi, mengasosiasi, dan mengomunikasikan (Indraswati, 2018). Keberhasilan guru dalam menyampaikan materi pelajaran bergantung pada kepercayaan diri dan kelancaran dalam berkomunikasi. Komunikasi memiliki peran penting dalam membentuk interaksi antara guru dan peserta didik. Dalam proses belajar, pola komunikasi yang digunakan antara lain komunikasi satu arah, komunikasi dua arah, dan komunikasi banyak arah. Salah satu kemampuan berkomunikasi yang penting dimiliki oleh seorang guru adalah kemampuan untuk berbicara di depan umum (Public speaking). Mahasiswa PGSD sebagai calon guru dituntut memiliki kompetensi komunikasi yang baik (Widodo, Husniati, Indraswati, Rahmatih, \& Novitasari, 2020). Komunikasi yang baik akan membawa dampak yang baik bagi masyarakat (Najla Amaly, 2018).

Menurut David Zarefsky (2013: 126) "Public speaking is a continous communication process in which messages and signals circulate back and forth between speakers and listeners". Public speaking merupakan seni dalam berbicara di depan umum dengan tujuan agar pendengar berpikir, merasakan, dan bertindak sesuai dengan harapan pembicara. Kemampuan public speaking dapat dilihat dari kemampuan melakukan presentasi, gesture tubuh, mampu berkonsentrasi, pengendalian emosi, perbendaharaan kata, dan mampu mengatasi demam panggung. Mahasiswa harus memiliki kemampuan literasi dan wawasan yang luas, salah satunya dengan memperbanyak bacaan (Widodo, A., Indraswati, D., Erfan, M., Maulyda, M. A., \& Rahmatih, 2020). Bagi sebagian orang berbicara di depan umum adalah perkara mudah, tetapi sebagian orang mengalami kecemasan berbicara di depan umum. Kecemasan merupakan suatu keadaan yang tidak nyaman yang ditandai oleh reaksi fisiologis dan psikologis. Reaksi fisiologis misalnya jantung berdebar, keringat dingin, nafas tidak teratur, dan tangan menjadi dingin. Reaksi psikologis misalnya gelisah, pesimis, takut, dan susah berkonsentrasi (Bukhori, 2016). Universitas Mataram, terutama fakultas keguruan dan ilmu pendidikan (FKIP) memiliki tujuan mencetak 
mahasiswanya menjadi guru berkualitas. Mahasiswa PGSD sebagai bagian dari FKIP dituntut sebagai calon guru yang harus memiliki kemampuan public speaking yang baik. Public speaking yang baik akan membentuk interaksi yang baik antara guru dengan peserta didik, sehingga potensi peserta didik dapat berkembang secara optimal (Arif Widodo, Dyah Indraswati, Deni Sutisna, Nursaptini, 2020). Pembelajaran yang interaktif dapat mengubah suasana belajar menjadi lebih aktif, kolaboratif, dan pasrtisipatif sehingga dapat meransang peserta didik berpikir kritis serta meningkatkan kemampuan kognitif, afektif, dan psikomotorik (Widodo \& Indraswati, 2019). Belajar akan optimal apabila peserta didik berpartisipasi aktif menyalurkan buah pikiran dan dan kreatifitasnya (Dyah Indraswati, Arif Widodo, Aisa Nikmah Rahmatih, Mohammad Archi Maulyda, 2020). Dalam rangka mendapatkan gambaran tentang kepercayaan diri mahasiswa dalam berbicara di depan umum, dilakukan wawancara terhadap sepuluh mahasiswa PGSD angkatan 2019 yang dipilih secara acak. Hasil temuan menunjukkan tujuh mahasiswa lebih memilih mendengar daripada berbicara di depan kelas. Hal ini dikarenakan mereka sering mengalami kecemasan karena kurangnya rasa percaya diri, khawatir melakukan kesalahan, serta tidak dapat menjawab pertanyaan temantemannya. Sementara itu, tiga mahasiswa yang lain merasa senang berbicara di depan kelas karena sudah terbiasa melakukan presentasi.

Berdasarkan hasil observasi yang dilakukan pada saat mahasiswa melakukan presentasi, ternyata dari 5 orang penyaji hanya ditemukan 1 atau 2 orang yang percaya diri dalam bebicara di depan umum sisanya masih kesulitan dalam berbicara di depan umum. Observasi ini dilakukan pada 9 kelas prodi PGSD angkatan 2019 pada mata kuliah pengantar pendidikan. Hal ini disebabkan salah satunya karena kurangnya kepercayaan diri mahasiswa. Kurangnya rasa percaya diri menyebabkan kecemasan tampil di depan umum. Kecemasan itu bisa disebabkan salah satunya karena kurangnya kemampuan berkomunikasi. Mahasiswa kurang mampu dalam mempengaruhi audiens karena kurang dalam penguasaan materi dan tidak adanya latihan sebelum presentasi.

Kepercayaan diri adalah keyakinan pada kemampuan yang dimiliki untuk mewujudkan suatu target atau tujuan. (Ady wibowo, 2010:40). Ciri seseorang yang memiliki kepercayaan tinggi antara lain: 1). Yakin pada kemampuan diri, hal ini membuat individu tidak butuh pujian, pengakuan, bahkan rasa hormat dari orang lain. 2) Tidak menunjukkan sikap yang konformis untuk diterima orang lain. 3) Mampu menjadi diri sendiri serta dapat menghadapi penolakan. 4). Memiliki kontrol emosi yang baik. 5). Tidak mudah putus asa. 6). Memiliki cara pandang positif. 7). Realistis pada harapan. (Fatimah, 2006: 149).

Menurut Rakhmat dalam Wahyuni kecemasan disebabkan oleh adanya pikiran-pikiran negatif. Seseorang menganggap orang lain tidak dapat menerimanya karena perbedaan yang dimiliki misalnya status sosial, ekonomi, atau tingkat pendidikan. Hal ini bisa membuat seseorang sulit mengomunikasikan gagasannya dan cenderung menghindar. Mahasiswa yang memiliki kepercayaan diri akan menganggap presentasi sebagai hal yang positif, sebuah proses belajar dan tantangan.(Wahyuni, 2014).

Berdasarkan uraian yang diatas, maka peneliti bermaksud untuk mencari pengaruh kepercayaan diri terhadap kemampuan public speaking, pengaruh keterampilan berkomunikasi terhadap kemampuan public speaking, dan pengaruh kepercayaan diri dan keterampilan berkomunikasi terhadap 
kemampuan public speaking Mahasiswa Pendidikan Guru Sekolah Dasar Angkatan 2019, Fakultas Keguruan dan IImu Pendidikan, Universitas Mataram.

\section{Metode Penelitian}

Populasi dalam penelitian ini adalah mahasiswa angkatan 2019 program studi Pendidikan Guru Sekolah Dasar, Fakultas Keguruan dan IImu Pendidikan, Universitas Mataram. Keseluruhan mahasiswa berjumlah 345, kemudian diambil $38 \%$ dari jumlah populasi atau sekitar 131 mahasiswa sebagai sampel. Pengambilan sampel dalam penelitian ini menggunakan Teknik simple random sampling. Teknik pengumpulan data dalam penelitian dengan menggunakan angket tertutup (Google Form) yang disebar menggunakan whatsapp. Angket ini digunakan untuk memperoleh informasi terkait kepercayaan diri, kemampuan berkomunikasi, dan public speaking. Alat ukur yang digunakan dalam penelitian ini menggunakan skala Likertyang dimodifikasi dengan empat alternatif jawaban yaitu selalu (SL), sering (SR), kadang-kadang (KD), dan tidak pernah (TP).

Teknik analisis data

1. Analisis statistik deskriptif

Mean, median, modus,dan standar deviasi

2. Uji prasyarat analisis meliputi uji normalitas, uji linearitas, dan uji multikolinieritas

3. Analisis Regresi

a. Uji Regresi Sederhana

1) Membuat garis regresi

2) Mencari koefisien determinasi $\left(r^{2}\right)$, antara $X_{1}$ dan $X_{2}$ terhadap $Y$

3) Mencari Nilai t

b. Uji Regresi Linier Berganda

1) Membuat persamaan garis regresi 3 prediktor

2) Mencari koefisien determinan antara kriterium $Y$ dengan prediktor $\mathrm{X}_{1}$ dan $\mathrm{X}_{2}$

3) Menguji signifikansi regresi ganda dengan uji $F$

4) Sumbangan Relative (SR)

5) Sumbangan Efektif (SE)

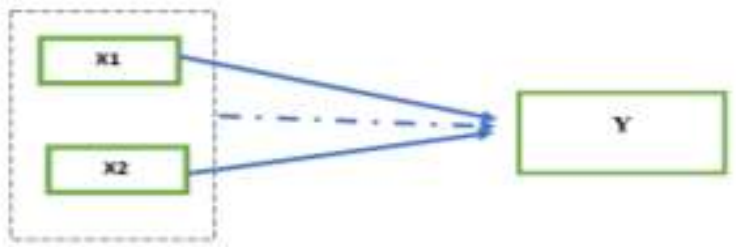

\section{Gambar 1. Paradigma Penelitian}

Keterangan

$\mathrm{X} 1$

: Kepercayaan diri

$\mathrm{X} 2$

:Kemampuan berkomunikasi

Y

:Kemampuan public speaking

: Pengaruh variabel $X$ (variabel bebas) terhadap variabel $Y$ 
(variabel terikat) secara parsial

: Pengaruh variabel $X$ (variabel bebas) terhadap variabel $Y$ (variabel terikat) secara simultan (Sugiyono: 194)

\section{Hasil Penelitian}

Terdapat tiga variabel dalam penelitian ini yaitu kepercayaan diri, kemampuan berkomunikasi, dan kemampuan public speaking.

Pengujian prasyarat analisis

\section{Uji Normalitas}

Tabel 1. One-Sample Kolmogorov-Smirnov Test

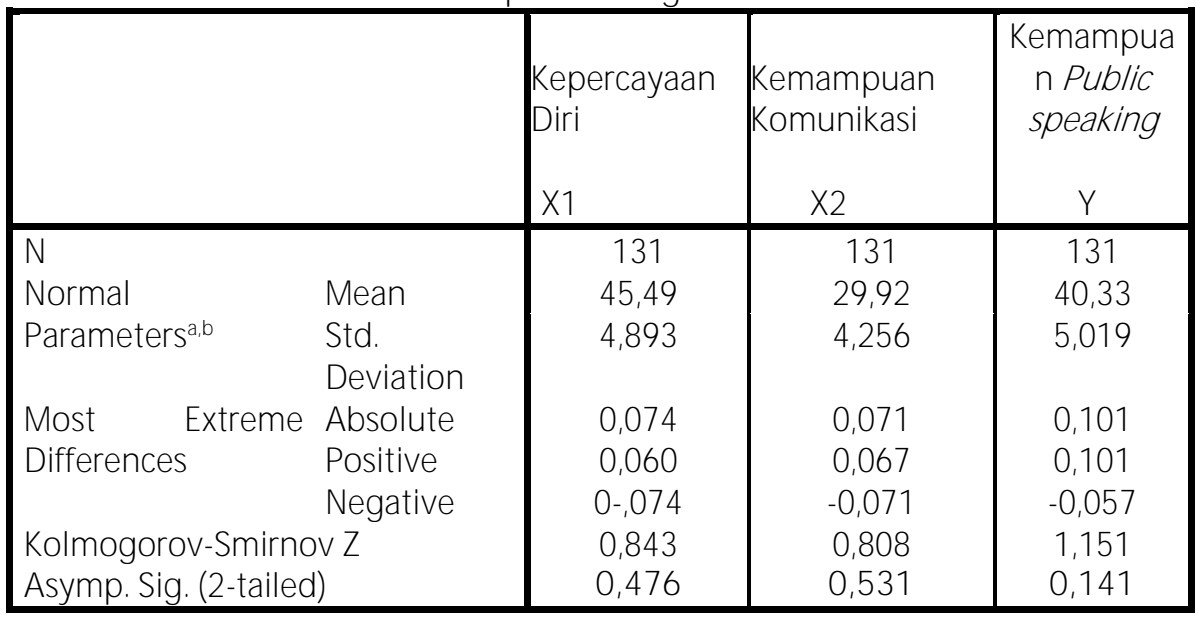

Tabel di atas menunjukkan hasil analisis uji normalitas terhadap ketiga variabel. Berdasarkan hasil analisis, nilai signifikansi (Asymp. Sig) dari variabel $\mathrm{X} 1$, X2, dan Y adalah 0,476,0,531, dan 0,141. Nilai Asymp. Sig ketiga variabel lebih besar dari 0,05 maka dapat disimpulkan bahwa data ketiga variabel berdistribusi normal.

\section{Uji Linearitas}

Tabel 2. Hubungan Kepercayaan Diri dan Kemampuan Public speaking (ANOVA)

\begin{tabular}{|c|c|c|c|c|c|c|c|}
\hline & $\begin{array}{l}\text { Sum of } \\
\text { Squares }\end{array}$ & df & Mean Square & $F$ & Sig. \\
\hline \multirow{5}{*}{$\begin{array}{l}\text { Public } \\
\text { speakin } \\
\mathrm{g} \\
\text { Keperc } \\
\text { ayaan } \\
\text { Diri }\end{array}$} & Between & (Combined) & 1381,472 & 22 & 62,794 & 3,582 & 0,000 \\
\hline & Groups & Linearity & 955,944 & 1 & 955,944 & 54,527 & 0,000 \\
\hline & & $\begin{array}{l}\text { Deviation } \\
\text { from } \\
\text { Linearity }\end{array}$ & 425,528 & 21 & 20,263 & 1,156 & 0,305 \\
\hline & \multicolumn{2}{|c|}{ Within Groups } & 1893,413 & 108 & 17,532 & & \\
\hline & \multicolumn{2}{|l|}{ Total } & 3274,885 & 130 & & & \\
\hline
\end{tabular}

Berdasarkan hasil analisis, nilai $\mathrm{F}$ yang ditemukan adalah sebesar 1,156 dengan sig 0,305. Oleh karena nilai sig lebih dari 0,05 maka dapat disimpulkan bahwa hubungan antara variabel kepercayaan diri dan kemampuan public speaking bersifat linier. 
Tabel 3. Hubungan Kemampuan Komunikasi dan Kemampuan Public speaking (ANOVA)

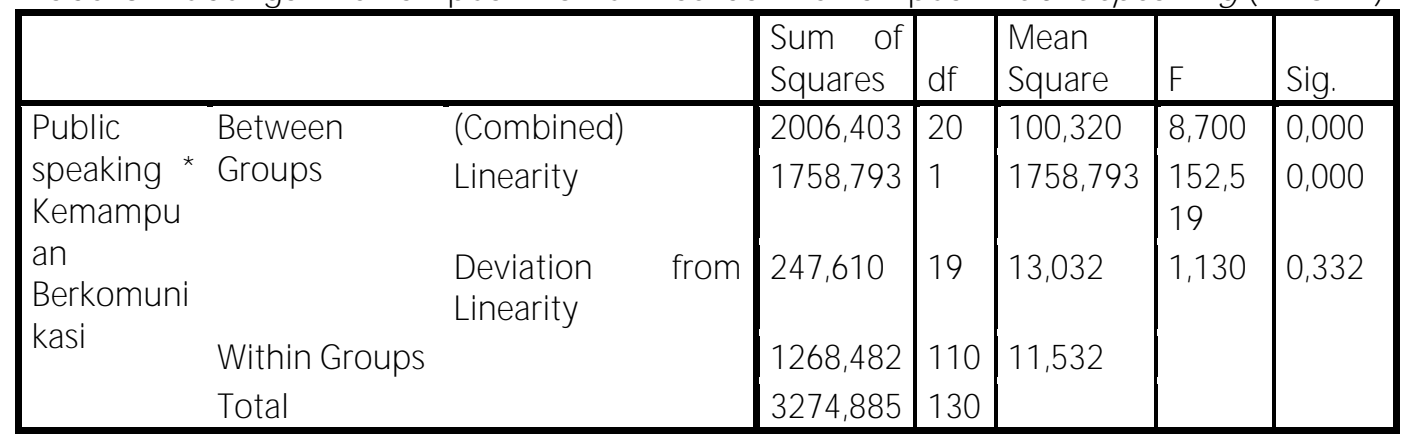

Berdasarkan hasil analisis, nilai $F$ yang ditemukan adalah sebesar 1,130 dengan sig 0,332. Oleh karena nilai sig lebih dari 0,05 maka dapat disimpulkan bahwa hubungan antara variabel kemampuan berkomunikasi dan kemampuan public speaking bersifat linier.

\section{Uji Multikolinearitas}

Tabel 4. Ringkasan Hasil Uji Multikolinearitas

\begin{tabular}{|l|l|c|c|}
\hline No. & \multicolumn{1}{|c|}{ Variabel } & VIF & \multicolumn{1}{c|}{ keterangan } \\
\hline 1. & Kepercayaan Diri $(\mathrm{X} 1)$ & 1,667 & Tidak Terjadi Multikolinearitas \\
\cline { 1 - 2 } & $\begin{array}{l}\text { Kemampuan Berkomunikasi } \\
(\mathrm{X} 2):\end{array}$ & 1,667 & \\
\hline
\end{tabular}

Berdasarkan tabel ringkasan hasil multikolinearitas dapat diketahui bahwa nilai VIF untuk variabel kepercayaan diri (X1) dan variabel kemampuan berkomunikasi (X2) adalah 1,667 lebih kecil dari 10,00 atau 2,667 <10,00 sehingga dapat disimpulkan bahwa tidak terjadi multikolinearitas.

\section{Analisis Regresi}

\section{Pertanyaan penelitian pertama}

Pertanyaan penelitian pertama yaitu mempertanyakan apakah terdapat pengaruh positif kepercayaan diri terhadap kemampuan public speaking mahasiswa PGSD angkatan 2019,FKIP, Universitas Mataram. Analisis pertama dilakukan dengan menggunakan analisis regresi sederhana dengan program SPSS v.18 for Windows. Ringkasan hasil analisis uji regresi dapat dilihat pada tabel.

Tabel 5. Hasil Uji Regresi Sederhana (X1-Y)

\begin{tabular}{|l|l|l|l|l|l|l|}
\hline Constant & $\begin{array}{l}\text { Unstandardized } \\
\text { Coeffiecient }\end{array}$ & $\mathrm{R}$ & $\mathrm{R}^{2}$ & $\begin{array}{l}\text { Adj R } \\
\text { Square }\end{array}$ & $\mathrm{T}_{\text {hitung }}$ & Sig. \\
\hline 15,120 & $0,554^{\prime}$ & 0,540 & 0,292 & 0,286 & $\begin{array}{l}7, \\
292\end{array}$ & 0,000 \\
\hline
\end{tabular}

\section{a. Persamaan Garis Regresi}

Berdasarkan tabel, maka persamaan garis regresi adalah sebagai berikut: $Y=15,120+0,554 X 1$. Persamaan tersebut menunjukkan bahwa nilai 
koefisien regresi bernilai positif sebesar 0,554 artinya apabila nilai kepercayaan diri meningkat satu poin maka nilai kemampuan public speaking akan meningkat sebesar 0,554.

b. Koefisien Korelasi (R) antara X1 dengan $Y$

Berdasarkan perhitungan dengan menggunakan program SPSS versi 18 for windows, didapatkan nilai koefisien korelasi (R) sebesar 0,540 artinya kepercayaan diri memiliki pengaruh positif terhadap kemampuan public speaking.

\section{c. Koefisien Determinasi (R2) antara X1 dengan $Y$}

Nilai koefisien determinasi $\left(R^{2}\right) X 1$ terhadap $Y$ sebesar 0,292 , artinya kontribusi/ sumbangan kepercayaan diri terhadap kemampuan public speaking adalah sebesar $29,2 \%$, sisanya $(70,8 \%)$ berasal dari variabel lain.

\section{d. Pengujian Signifikansi dengan Uji t}

Berdasarkan hasil perhitungan diketahui bahwa nilai $t_{\text {hitung }}>t_{\text {tabel }}(7,292$ 1,656 ) dengan signifikansi sebesar 0,000 <0,05, maka dapat disimpulkan bahwa kepercayaan diri memiliki pengaruh signifikan terhadap kemampuan public speaking. Berdasarkan hasil uraian analisis regresi sederhana dapat diperoleh jawaban untuk pertanyaan penelitian pertama yaitu terdapat pengaruh kepercayaan diri terhadap kemampuan public speaking mahasiswa PGSD angkatan 2019, FKIP, Universitas Mataram.

\section{Pertanyaan Penelitian Kedua}

Pertanyaan penelitian kedua yaitu mempertanyakan apakah terdapat pengaruh positif kemampuan komunikasi terhadap kemampuan public speaking mahasiswa PGSD angkata 2019, FKIP, Universitas Mataram. Analisis kedua dilakukan dengan menggunakan analisis regresi sederhana.

Tabel 6. Ringkasan Hasil Uji Regresi Sederhana (X2-Y)

\begin{tabular}{|l|l|l|l|l|l|l|}
\hline Constant & $\begin{array}{l}\text { Unstandardized } \\
\text { Coeffiecient }\end{array}$ & $\mathrm{R}$ & $\mathrm{R}^{2}$ & $\begin{array}{l}\text { Adj R } \\
\text { Square }\end{array}$ & $\mathrm{T}_{\text {hitung }}$ & Sig. \\
\hline 14,470 & 0,865 & 0,733 & 0,537 & 0,533 & 12,333 & 0,000 \\
\hline
\end{tabular}

\section{a. Persamaan Garis Regresi}

Berdasarkan tabel, maka persamaan garis regresi adalah sebagai berikut: $Y=14,470+0,865 X 2$. Persamaan tersebut menunjukkan bahwa nilai koefisien regresi bernilai positif sebesar 0,865 artinya apabila nilai kemampuan komunikasi meningkat satu poin maka nilai kemampuan public speaking akan meningkat sebesar 0,865.

b. Koefisien Korelasi (R) antara X2 dengan $Y$

Berdasarkan perhitungan dengan menggunakan program SPSS versi 18 for windows, didapatkan nilai koefisien korelasi (R) sebesar 0,733 artinya kemampuan komunikasi memiliki pengaruh positif terhadap kemampuan public speaking.

c. Koefisien Determinasi $\left(\mathbf{R}^{2}\right)$ antara $X 2$ dengan $Y$

Nilai koefisien determinasi $\left(R^{2}\right) X_{2}$ terhadap $Y$ sebesar 0,537, artinya kontribusi/ sumbangan kemampuan komunikasi terhadap kemampuan public speaking adalah sebesar $53,7 \%$, sisanya ( $46,3 \%$ ) berasal dari variabel lain. 


\section{d. Pengujian Signifikansi dengan Uji t}

Berdasarkan hasil perhitungan diketahui bahwa nilai $t_{\text {hitung }}>t_{\text {tabel }}(12,333$ $>1,656$ ) dengan signifikansi sebesar $0,000<0,05$, maka dapat disimpulkan bahwa kemampuan komunikasi memiliki pengaruh signifikan terhadap kemampuan public speaking. Berdasarkan hasil uraian analisis regresi sederhana dapat diperoleh jawaban untuk pertanyaan penelitian kedua yaitu terdapat pengaruh kemampuan komunikasi terhadap kemampuan public speaking mahasiswa PGSD angkatan 2019, FKIP, Universitas Mataram.

\section{Pertanyaan Penelitian Ketiga}

Pertanyaan penelitian ketiga mempertanyakan apakah terdapat pengaruh positif kepercayaan diri dan kemampuan komunikasi secara bersama-sama terhadap kemampuan public speaking mahasiswa PGSD angkatan 2019, FKIP, Universitas Mataram. Analisis ketiga dilakukan dengan menggunakan analisis regresi ganda.

\section{Tabel 7. Pengaruh Kepercayaan Diri dan Kemampuan Komunikasi Terhadap Kemampuan Public Speaking}

\begin{tabular}{|c|c|c|c|c|}
\hline Model & $\mathrm{R}$ & R Square & $\begin{array}{c}\text { Adjusted R } \\
\text { Square }\end{array}$ & $\begin{array}{c}\text { Std. Error of } \\
\text { the Estimate }\end{array}$ \\
\hline 1. & $0,739(\mathrm{a}):$ & 0,547 & 0,540 & 3,405 \\
\hline
\end{tabular}

$\mathrm{R}=0,739$ artinya koefisien korelasinya sebesar 0,739. Angka menunjukkan derajad korelasi antara variabel kepercayaan diri dan kemampuan komunikasi dengan kemampuan public speaking. $\mathrm{R}$ Square $=$ 0,547 menunjukkan angka koefisien determinasinya (R2). Artinya variansi dalam kemampuan public speaking dapat dijelaskan oleh kepercayaan diri dan kemampuan komunikasi melalui model sebesar $54,7 \%$, sisanya $(45,3 \%)$ berasal dari variabel lain. Atau dengan bahasa sederhana besarnya kontribusi kepercayaan diri dan kemampuan komunikasi terhadap kemampuan public speaking adalah sebesar $54,7 \%$, sisanya $(45,3 \%)$ berasal dari variabel lain.

Adjusted $R$ square $=0,540$. Ukuran ini maknanya sama dengan $R$ square, hanya saja Adjusted $\mathrm{R}$ square ini nilainya lebih stabil karena sudah disesuaikan dengan jumlah variabel bebasnya. Standard Error of The Estimate $=3,405$ yang menunjukkan ukuran tingkat kesalahan dalam melakukan prediksi terhadap variabel terikat.

Tabel 8. ANOVA

\begin{tabular}{|l|l|l|l|l|l|}
\hline Model & $\begin{array}{l}\text { Sum of } \\
\text { Squares }\end{array}$ & df & $\begin{array}{l}\text { Mean } \\
\text { Square }\end{array}$ & F & Sig. \\
\hline Regression & 1790,891 & 2 & 895,446 & 77,235 & $0,000^{\text {a }}$ \\
Residual & 1483,994 & 128 & 11,594 & & \\
Total & 3274,885 & 130 & & & \\
\hline
\end{tabular}

a. Predictors: (Constant), X2, X1

b. Dependent Variable: $Y$

Bagian ini menampilkan hasil pengujian koefisien determinasi. Hasil pengujian tersebut ditemukan harga $\mathrm{F}$ hitung sebesar 77,235 dengan Sig. = 
0,000 . Oleh karena nilai sig. $<0,05$ maka Ho $(\rho=0)$ ditolak yang artinya kepercayaan diri dan kemampuan komunikasi secara simultan memiliki pengaruh yang signifikan terhadap kemampuan public speaking.

Tabel 9. Coefficients ${ }^{\mathrm{a}}$

\begin{tabular}{|c|c|c|c|c|c|}
\hline \multirow[t]{2}{*}{ Model } & \multicolumn{2}{|c|}{$\begin{array}{l}\text { Unstandardized } \\
\text { Coefficients }\end{array}$} & \multirow{2}{*}{$\begin{array}{l}\text { Standard } \\
\text { ized } \\
\text { Coefficie } \\
\text { nts } \\
\text { Beta }\end{array}$} & \multirow[b]{2}{*}{$\mathrm{t}$} & \multirow[b]{2}{*}{ Sig. } \\
\hline & B & $\begin{array}{l}\text { Std. } \\
\text { Error }\end{array}$ & & & \\
\hline $\begin{array}{l}\text { (Const } \\
\text { ant) }\end{array}$ & 11,359 & 2,827 & & 4,018 & 0,000 \\
\hline $\mathrm{X} 1$ & 0,131 & 0,079 & 0,128 & 1,664 & 0,099 \\
\hline $\mathrm{X} 2$ & 0,769 & 0,091 & 0,652 & 8,486 & 0,000 \\
\hline
\end{tabular}

Persamaan garis regresinya: $\gamma^{\prime}=11,359+0,131 \times 1+0,769 \times 2$. Untuk menguji koefisien garisnya dapat dilihat pada kolom $t$ dan sig. Pengujian koefisien garis regresi dilakukan sebagai berikut. Untuk variabel kepercayaan diri (X1): ditemukan nilai $b 1=0,131$ dengan $t=1,664$ dan sig. $=0,099$. Oleh karena nilai sig. $>0,05$ maka $\mathrm{Ho}\left(\beta_{1}=0\right)$ diterima yang artinya variabel kepercayaan diri tidak berpengaruh terhadap kemampuan public speaking jika kemampuan komunikasi dikendalikan/dikontrol. Untuk variabel kemampuan komunikasi (X2) ditemukan nilai $b 2=0,769$ dengan $t=8,486$ dan Sig. $=0,000$. Oleh karena nilai sig. $<0,05$ maka $\mathrm{Ho}\left(\beta_{2}=0\right)$ ditolak yang artinya variabel kemampuan komunikasi berpengaruh positif terhadap kemampuan public speaking jika variabel kepercayaan diri dikendalikan/dikontrol.

\section{Sumbangan Relatif (SR) dan Sumbangan Efektif (SE)}

Berdasarkan hasil analisis regresi ganda dapat diketahui besarnya Sumbangan Relatif (SR) dan Sumbangan Efektif (SE) masing-masing variabel bebas (kepercayaan diri dan kemampuan komunikasi) dan variabel terikat (kemampuan public speaking).

Ringkasan Hasil Perhitungan Sumbangan Relative dapat dilihat pada tabel dibawah ini:

Tabel 10. Correlations

\begin{tabular}{|ll|l|l|l|}
\hline & & $\mathrm{X} 1$ & $\mathrm{X} 2$ & $\mathrm{Y}$ \\
\hline $\mathrm{X} 1$ & Pearson Correlation & 1 & $0,633^{* *}$ & $0,540^{* *}$ \\
& Sig. (2-tailed) & & 0,000 & 0,000 \\
& $\mathrm{~N}$ & 131 & 131 & 131 \\
\hline $\mathrm{X} 2$ & Pearson Correlation & $0,633^{* *}$ & 1 & $0,733^{* *}$ \\
& Sig. (2-tailed) & 0,000 & & 0,000 \\
& $\mathrm{~N}$ & 131 & 131 & 131 \\
\hline $\mathrm{Y}$ & Pearson Correlation & $0,540^{* *}$ & $0,733^{* *}$ & 1 \\
& Sig. (2-tailed) & 0,000 & 0,000 &
\end{tabular}




\begin{tabular}{|l|l|l|l|}
\hline $\mathrm{N}$ & 131 & 131 & 131 \\
\hline **. Correlation is significant at the 0.01 level (2-tailed).
\end{tabular}

Tabel 11. Model Summary

\begin{tabular}{|c|c|c|c|c|c|c|c|c|c|c|}
\hline \multirow[b]{2}{*}{$\begin{array}{l}\text { Mo } \\
\text { del }\end{array}$} & \multirow[b]{2}{*}{$\mathrm{R}$} & \multirow[b]{2}{*}{$\begin{array}{c}\mathrm{R} \\
\text { Squ } \\
\text { are }\end{array}$} & \multirow[b]{2}{*}{$\begin{array}{c}\text { Adju } \\
\text { sted } \\
\text { R } \\
\text { Squa } \\
\text { re }\end{array}$} & \multirow[b]{2}{*}{$\begin{array}{c}\text { Std. } \\
\text { Error } \\
\text { of } \\
\text { the } \\
\text { Esti } \\
\text { mate }\end{array}$} & \multicolumn{5}{|c|}{ Change Statistics } & \multirow[b]{2}{*}{$\begin{array}{l}\text { Durb } \\
\text { in- } \\
\text { Wats } \\
\text { on }\end{array}$} \\
\hline & & & & & $\begin{array}{l}\text { R } \\
\text { Squ } \\
\text { are } \\
\text { Cha } \\
\text { nge }\end{array}$ & $\begin{array}{l}\text { F } \\
\text { Cha } \\
\text { nge }\end{array}$ & $\begin{array}{l}\mathrm{df} \\
1\end{array}$ & $\begin{array}{l}\text { Df } \\
2\end{array}$ & $\begin{array}{l}\text { Sig. } \\
\text { FCha } \\
\text { nge }\end{array}$ & \\
\hline 1 & $\begin{array}{l}0,7 \\
39^{a}\end{array}$ & $\begin{array}{l}0,5 \\
47\end{array}$ & 0.540 & $\begin{array}{l}3,40 \\
5\end{array}$ & $\begin{array}{l}0,54 \\
7\end{array}$ & $\begin{array}{l}77,2 \\
35\end{array}$ & 2 & $\begin{array}{l}1 \\
2 \\
8\end{array}$ & $\begin{array}{l}0,00 \\
0\end{array}$ & $\begin{array}{l}1,8 \\
22\end{array}$ \\
\hline
\end{tabular}

Tabel 12. Coefficients ${ }^{\mathrm{a}}$

\begin{tabular}{|c|c|c|c|c|c|c|c|c|c|c|}
\hline \multirow[t]{2}{*}{$\begin{array}{c}\text { Mod } \\
\text { el }\end{array}$} & \multicolumn{2}{|c|}{$\begin{array}{l}\text { Unstandardiz } \\
\text { ed } \\
\text { Coefficients }\end{array}$} & \multirow{2}{*}{$\begin{array}{c}\text { Standardized } \\
\text { Coefficients } \\
\text { Beta }\end{array}$} & \multirow[b]{2}{*}{$\mathrm{t}$} & \multirow[b]{2}{*}{ Sig. } & \multicolumn{3}{|c|}{ Correlations } & \multicolumn{2}{|c|}{$\begin{array}{c}\text { Collinearity } \\
\text { Statistics }\end{array}$} \\
\hline & B & $\begin{array}{c}\text { Std. } \\
\text { Error }\end{array}$ & & & & $\begin{array}{l}\text { Zero- } \\
\text { order }\end{array}$ & Partial & Part & $\begin{array}{l}\text { Toler } \\
\text { ance }\end{array}$ & VIF \\
\hline $\begin{array}{l}\text { (Con } \\
\text { stant } \\
\text { ) }\end{array}$ & $\begin{array}{l}11,35 \\
9\end{array}$ & 2,827 & & $\begin{array}{l}4,01 \\
8\end{array}$ & $\begin{array}{l}, 00 \\
0\end{array}$ & & & & & \\
\hline $\mathrm{X} 1$ & 0,131 & 0,079 & 0,128 & $\begin{array}{l}1,66 \\
4\end{array}$ & $\begin{array}{l}, 09 \\
9\end{array}$ & 0,540 & 0,146 & $\begin{array}{l}0,09 \\
9\end{array}$ & 0,600 & $\begin{array}{l}1,66 \\
7\end{array}$ \\
\hline$x 2$ & 0,769 & 0,091 & 0,652 & $\begin{array}{l}8,48 \\
6\end{array}$ & $\begin{array}{l}, 00 \\
0\end{array}$ & 0,733 & 0,600 & $\begin{array}{l}0,50 \\
5\end{array}$ & 0,600 & $\begin{array}{l}1,66 \\
7\end{array}$ \\
\hline
\end{tabular}

Tabel 13.Ringkasan hasil dari analisis korelasi dan regresi

\begin{tabular}{|c|c|c|c|}
\hline Variabel & $\begin{array}{c}\text { Koefisien Regresi } \\
(\text { Beta) }\end{array}$ & $\begin{array}{c}\text { Koefisien Korelasi } \\
(\mathrm{r})\end{array}$ & R \\
\cline { 1 - 3 } Xquare \\
\hline $\mathrm{X} 1$ & 0,128 & $0,540^{* *}$ & \multirow{2}{*}{0,547} \\
\hline
\end{tabular}

Sumbangan efektif variabel kepercayaan diri (X1) terhadap kemampuan public speaking

$\mathrm{SE}(\mathrm{X} 1) \%=\mathrm{BX} 1 \times \mathrm{rxy} \times 100 \%$

$\mathrm{SE}(\mathrm{X} 1) \%=0,128 \times 0,540 \times 100 \%$

$\mathrm{SE}(\mathrm{X} 1) \%=6,91 \%$

Sumbangan efektif variabel kemampuan komunikasi (X2) terhadap kemampuan public speaking

SE $(X 2) \%=B X 2 \times r \times y \times 100 \%$

SE $(X 2) \%=0,652 \times 0,733 \times 100 \%$

SE $(X 2) \%=47,79 \%$ 
Sumbangan efektif total dapat dihitung sebagai berikut:

$\mathrm{SE}$ total $=\mathrm{SE}(\mathrm{X} 1) \%+\mathrm{SE}(\mathrm{X} 2) \%$

SE total $=6,91 \%+47,79 \%$

SE total $=54,7 \%$

Berdasarkan hasil perhitungan di atas dapat diketahui bahwa sumbangan efektif (SE) variabel kepercayaan diri (X1) terhadap kemampuan public speaking (Y) adalah sebesar 6,91\%. Sementara sumbangan efektif (SE) variabel kemampuan komunikasi (X2) terhadap kemampuan komunikasi (Y) adalah sebesar $47,79 \%$. Dengan demikian dapat disimpulkan bahwa variabel X2 memiliki pengaruh lebih dominan terhadap variabel Y. Untuk total SE adalah sebesar $54,7 \%$ atau sama dengan koefisien determinasi (Rsquare) analisis regresi yakni $54,7 \%$.

Sumbangan relatif variabel kepercayaan diri (X1) terhadap kemampuan public speaking $(Y)$

$\mathrm{SR}(\mathrm{X} 1) \%=\mathrm{SE}(\mathrm{X} 1) \% / \mathrm{R}^{2}$

$\mathrm{SR}(\mathrm{X} 1) \%=6,91 \% / 54,7 \%$

$\mathrm{SR}(\mathrm{X}) \%=12,63 \%$

Sumbangan relatif variabel kemampuan komunikasi (X2) terhadap kemampuan public speaking $(\mathrm{Y})$

$\mathrm{SR}(\mathrm{X} 2) \%=\mathrm{SE}(\mathrm{X} 2) \% / \mathrm{R}^{2}$

$\operatorname{SR}(X 2) \%=47,79 \% / 54,7 \%$.

$\mathrm{SR}(\mathrm{X}) \%=87,37 \%$

Sumbangan relatif (SR) total dapat dihitung sebagai berikut:

$\mathrm{SR}$ total $=\mathrm{SR}(\mathrm{X} 1) \%+\mathrm{SR}(\mathrm{X} 2) \%$

SR total $=12,63 \%+87,37 \%$

SR total $=100 \%$

Sumbangan relatif (SR) variabel kepercayaan diri (X1) terhadap kemampuan public speaking $(Y)$ adalah sebesar $12,63 \%$. Sementara sumbangan relatif (SR) variabel kemampuan komunikasi (X2) terhadap kemampuan public speaking $(\mathrm{Y})$ adalah sebesar $87,37 \%$. Untuk total SR adalah sebesar $100 \%$ atau sama dengan 1.

\section{Pembahasan}

Tujuan dari penelitian ini adalah untuk menguji pengaruh kepercayaan diri, kemampuan komunikasi terhadap kemampuan public speaking mahasiswa prodi PGSD angkatan 2019, FKIP, Universitas Mataram. Analisis regresi dalam penelitian ini adalah sebagai berikut:

1. Pengaruh kepercayaan diri terhadap kemampuan public speaking mahasiswa prodi PGSD, FKIP, Universitas Mataram

Hasil penelitian menunjukkan terdapat pengaruh positif dan signifikan kepercayaan diri terhadap kemampuan public speaking mahasiswa prodi 
PGSD, FKIP, universitas mataram. Berdasarkan hasil analisis regresi sederhana dengan bantuan SPSS versi 18 for Windows diperoleh koefisien korelasi (R) sebesar 0,540 dengan signifikansi 0,000. Nilai koefisien determinasi $\left(R^{2}\right)$ sebesar 0,292 yang menunjukkan bahwa variabel kepercayaan diri memiliki pengaruh terhadap kemampuan public speaking sebesar 29,2\%, sedangkan sisanya 70,8\% terdapat faktor atau variabel lain yang mempengaruhi kemampuan public speaking. Pengujian signifikansi dengan uji t diperoleh nilai $t_{\text {hitung }}$ sebesar 7, 292 dan $t_{\text {tabel }}$ pada taraf signifikansi $5 \%$ sebesar 1,656. Hal ini menunjukkan $t_{\text {hitung }}>t_{\text {tabel }}$ sehingga dapat dinyatakan bahwa terdapat pengaruh positif dan signifikan kepercayaan diri terhadap kemampuan public speaking. Semakin tinggi kepercayaan diri mahasiswa maka semakin tinggi pula kemampuan mahasiswa untuk tampil di depan umum (public speaking).

2. Pengaruh kemampuan komunikasi terhadap kemampuan public speaking mahasiswa

Hasil penelitian menunjukkan terdapat pengaruh positif dan signifikan kemampuan komunikasi terhadap kemampuan public speaking mahasiswa prodi PGSD, FKIP, Universitas Mataram. Berdasarkan hasil analisis regresi sederhana diperoleh nilai koefisien korelasi (R) sebesar 0,733 dengan signifikansi 0,000 . Nilai koefisien korelasi $\left(R^{2}\right)$ sebesar 0,537 yang menunjukkan bahwa variabel kemampuan komunikasi memiliki pengaruh terhadap kemampuan public speaking sebesar 53,7\% sedangkan sisanya $46,3 \%$ terdapat faktor atau variabel lain yang mempengaruhi kemampuan public speaking. Pengujian signifikansi dengan uji t diperoleh nilai $t_{\text {hitung }}$ sebesar 12,333 dan tabel pada taraf signifikansi 5\% sebesar 1,656. Hal ini menunjukkan $t_{\text {hitung }}>t_{\text {tabel }}$ sehingga dapat dinyatakan bahwa terdapat pengaruh positif dan signifikan kemampuan komunikasi terhadap kemampuan public speaking. Mahasiswa yang memiliki kemampuan komunikasi yang tinggi menjadikan individu tersebut mampu tampil berbicara di depan umum (public speaking).

3. Pengaruh kepercayaan diri dan kemampuan komunikasi terhadap kemampuan public speaking mahasiswa prodi PGSD, FKIP, Universitas Mataram.

Hasil penelitian menunjukkan terdapat pengaruh positif dan signifikan variabel kepercayaan diri dan kemampuan komunikasi secara simultan terhadap kemampuan public speaking mahasiswa prodi PGSD, FKIP, Universitas Mataram. Hasil uji F menunjukkan $F_{\text {hitung }}$ sebesar 77,235 dengan signifikansi $0,000(<0,05)$ sehingga dinyatakan bahwa variabel kepercayaan diri dan kemampuan komunikasi secara simultan berpengaruh secara signifikan terhadap kemampuan public speaking. Nilai koefisien determinasi $\left(R^{2}\right)$ sebesar 0,547, maka model regresi variabel kepercayaan diri dan kemampuan komunikasi dapat menjelaskan kemampuan public speaking sebesar 54,7\%. Angka ini menunjukkan bahwa kepercayaan diri dan kemampuan komunikasi memiliki pengaruh terhadap kemampuan public speaking sebesar 54,7\% sedangkan sisanya sebesar 45,3\% dipengaruhi oleh variabel lain di luar penelitian ini.

\section{Simpulan}


Berdasarkan pembahasan yang telah diuraikan, maka diperoleh kesimpulan sebagai berikut.

1. Terdapat pengaruh positif dan signifikan kepercayaan diri terhadap kemampuan public speaking mahasiswa prodi PGSD, FKIP, Universitas Mataram. Adanya pengaruh positif dibuktikan dengan nilai signifikansi 0,000 $<0,05$. Adapun besar pengaruh kepercayaan diri terhadap kemampuan public speaking yaitu dilihat dari nilai koefisien determinasi $\left(R^{2}\right)$ sebesar 0,292 menunjukkan bahwa kepercayaan diri memiliki pengaruh terhadap kemampuan public speaking mahasiswa sebesar $29,2 \%$.

2. Terdapat pengaruh positif dan signifikan kemampuan berkomunikasi terhadap kemampuan public speaking mahasiswa prodi PGSD, FKIP, Universitas Mataram. Adanya pengaruh positif dibuktikan dengan nilai signifikansi $0,000<0,05$. Adapun besar pengaruh kemampuan komunikasi terhadap kemampuan public speaking dilihat dari nilai koefisien determinasi $\left(\mathrm{R}^{2}\right)$ sebesar 0,537 menunukkan bahwa kemampuan komunikasi memiliki pengaruh terhadap kemampuan public speaking sebesar 53,7\%.

3. Terdapat pengaruh positif dan signifikan kepercayaan diri dan kemampuan komunikasi terhadap kemampuan public speaking mahasiswa prodi PGSD, FKIP, Universitas Mataram. Adanya pengaruh positif dibuktikan dengan hasil regresi uji $\mathrm{F}$ dengan nilai $\mathrm{F}$ hitung sebesar 77,235 dengan nilai signifikansi $0,000<0,05$. Adapun besar pengaruh kepercayaan diri dan kemampuan komunikasi secara bersama-sama terhadap kemampuan public speaking mahasiswa yaitu dilihat dari nilai koefisien determinasi $\left(R^{2}\right)$ sebesar 0,547 . Artinya, kepercayaan diri dan kemampuan komunikasi memiliki pengaruh terhadap kemampuan public speaking sebesar $54,7 \%$ sedangkan sisanya sebesar 45,3\% dipengaruhi oleh variabel lain di luar penelitian ini.

\section{Referensi}

Ady Wibowo, I. P. 2010. Memperkuat Kepercayaan Diri Anak Melalui Percakapan Referensial. Jurnal Pendidikan Penabur. 15. Hal 37 - 49.

Arif Widodo, Dyah Indraswati, Deni Sutisna, Nursaptini, S. N. (2020). Identifikasi Bakat Peserta Didik Berkebutuhan Khusus (Pdbk) Di Madrasah Inklusi Kabupaten Lombok. Jurnal Pendidikan Inklusi UPI), 3(2), 102-116. https://doi.org/http://dx.doi.org/10.26740/inklusi.v3n2.p102-116

Arif Widodo, Dyah Indraswati, A. R. (2020). Analisis Penggunaan Media Gambar Berseri Untuk Meningkatkan Kemampuan Membaca Siswa Disleksia Di Sekolah Dasar. Magistra: Media Pengembangan IImu Pendidikan Dasar Dan Keislaman, 11(1), 121. https://doi.org/http://dx.doi.org/10.31942/mgs.v11i1.3457.

Bukhori, B. (2016). Kecemasan berbicara di depan umum ditinjau dari kepercayaan diri dan keaktifan dalam organisasi kemahasiswaan. Jurnal Komunikasi Is/am, 6(1), 158-186. https://doi.org/10.15642/JKI.2016.6.1.158-186.

David Zarefsky. (2013). Public speaking: Strategies for Success. USA: Pearson. Edisi-7.

Deni Sutisna, Dyah Indraswati, Nursaptini, Setiani Novitasari, M. S. (2020). Penerapan Program Pendidikan Inklusi Di SDN 1 Sangkawana Lombok Tengah. Progres Pendidikan, 1(2), 115-127. 
Dyah Indraswati, Arif Widodo, Aisa Nikmah Rahmatih, Mohammad Archi Maulyda, M. E. (2020). Implementasi Sekolah Ramah Anak Dan Keluarga Di Sdn 2 Hegarsari, Sdn Kaligintung, Dan Sdn 1 Sangkawana. JKKP: Jurnal Kesejahteraan Kelaurga Dan Pendidikan, 7(April), 51-62. https://doi.org/: http://doi.org/10.21009/J KKP.071.05

Fatimah, E. 2006. Psikologi Perkembangan. Pustaka Setia: Bandung.

Indraswati, D. (2018). Efektivitas Model Pembelajaran Kooperatif Tipe Numbered Heads Together ( NHT ) Terhadap: Kompetensi Sikap Siswa, Kompetensi. Journal Research and Analysis: Economy, 1(2), 52-58. Retrieved from https://journal.stkipsingkawang.ac.id/index.php/J RAE/article/view/953.

Indraswati, D., Marhayani, D. A., Sutisna, D., \& Widodo, A. (2020). Critical Thinking Dan Problem Solving Dalam Pembelajaran Ips Untuk Menjawab Tantangan. Sosial Horizon, 71), 12-28. https://doi.org/10.31571/sosial.v7i1.1540.

Najla Amaly, D. I. (2018). Beauty Vlogger sebagai Media Pembentuk Tren Kecantikan di Indonesia. In M. P. Dr. Zainal Pikri, M.Ag., MA. Dr. Hj. Halimatus Sakdiah, S.Ag., M.Si. Armiah, S.IP., M.Si. Najla Amaly, S.Ikom., M.Med.Kom. Dyah Indraswati, S.Pd. (Ed.), The International Seminar "Dakwah, Local Wisdom, and Transnational Islam" (pp. 301-310). Retrieved from http://fdk.uinantasari.ac.id/index.php/download/proceeding-the-international-seminardakwah-local-wisdom-and-transnational-islam/.

Sugiyono. 2018. Metode Penelitian Kuantitatif, Kualitatif, dan R\&D. Bandung: Alfabeta

Sutisna, D., Indraswati, D., \& Sobri, M. (2019). Keteladanan Guru sebagai Sarana Penerapan Pendidikan Karakter Siswa. Jurnal Pendidikan Dasar Indonesia, 4(2), 29-33. https://doi.org/http://dx.doi.org/10.26737/jpdi.v4i2.1236.

Wahyuni, S. (2014). Hubungan antara Kepercayaan Diri dengan Kecemasan Berbicara di Depan Umum pada Mahasiswa Psikologi. E-Journal Psikologi, 2(1), 50-62.

Widodo, A., Indraswati, D., Erfan, M., Maulyda, M. A., \& Rahmatih, A. I. (2020). Profil minat baca mahasiswa baru PGSD Universitas Mataram. Premiere Educandum : Jurnal Pendidikan Dasar Dan Pembelajaran, 10(February), 34-48. https://doi.org/10.25273/pe.v10i1.5968.

Widodo, A., Husniati, H., Indraswati, D., Rahmatih, A. N., \& Novitasari, S. (2020). Prestasi belajar mahasiswa PGSD pada mata kuliah pengantar pendidikan ditinjau dari segi minat baca. Jurnal Bidang Pendidikan Dasar, 4(1), 26-36. https://doi.org/https://doi.org/10.21067/jbpd.v4i1.3808.

Widodo, A., \& Indraswati, D. (2019). Analisis Konten HOTS dalam Buku Siswa Kelas V Tema 6 "Panas dan Perpindahannya "Kurikulum 2013. Madrasah, 12(1), 1-13. https://doi.org/http://dx.doi.org/10.18860/mad.v12i1.7744.

Widodo, A., Indraswati, D., Novitasari, S., Rahmatih, A. N., \& Mataram, U. (2020). The Interest Of Learning Local Script Sasambo Of Pgsd Students At University Of Mataram. Primary: Jurnal Pendidikan Guru Sekolah Dasar, 9(3), 288-302. https://doi.org/http://dx.doi.org/10.33578/jpfkip.v9i1.7895.

Widodo, A., Indraswati, D., \& Sobri, M. (2019). Analisis Nilai-Nilai Kecakapan Abad 21 Dalam Buku Siswa SD/MI Kelas V Sub Tema 1 Manusia dan Lingkungan. Jurnal Tarbiyah: Jurnal Ilmiah Kependidikan, 8(2), 125-133. 
https://doi.org/10.18592/tarbiyah.v8i2.3231 